Arch. Tierz., Dummerstorf 50 (2007) 4, 374-380

Research Institute of Animal Production, Nitra, Slovakia

JAN BROUCEK, PETER KISAC, STEFAN MIHINA, ANTON HANUS, MICHAL UHRINCAT and VLADIMIR TANCIN

\title{
Hair whorls of Holstein Friesian heifers and affects on growth and behaviour
}

\begin{abstract}
The aim of this study was to investigate whether the growth, number of crossed squares in the open-field test and time of traversing the maze in the maze are affected by the height position of they facial whorl in heifers which were kept in experimental conditions. Fifty-eight Holstein heifers were used. The hair whorl position was determined as hair whorl high, middle and low. Heifers with a high whorl had significantly higher body weight at days $360(\mathrm{P}<0.05)$ and $540(\mathrm{P}<0.01)$ and average daily gains from birth to 21 months $(\mathrm{P}<0.001)$ and from the $6^{\text {th }}$ to 21 st months $(\mathrm{P}<0.01)$ of age. We did not find any significant differences among hair whorl position groups either in open-field tests or in the maze. The present results show that the growth is influenced in the investigated dairy cattle by height of their facial whorl.
\end{abstract}

Key Words: dairy heifers, hair whorl, growth, behaviour, Holstein Friesian

\section{Zusammenfassung}

Titel der Arbeit: Einfluss von Gesichtshaarwirbeln bei Holstein Friesian Färsen auf Wachstum und Verhalten

Das Ziel dieser Arbeit war es zu untersuchen, ob das Wachstum, die Zahl der überschrittenen Quadrate im OpenField Test und die Zeit der Labyrinthdurchquerungen durch die Position der Gesichtshaarwirbel bei Färsen beeinflusst werden. Die achtundfünfzig einbezogenen Holstein Friesian Färsen wurden unter experimentellen Bedingungen gehalten. Nach der Position der Haarwirbel wurden die drei Gruppen hoch, mittel und tief gebildet. Färsen mit hoch platziertem Wirbel hatten sowohl am 360. als auch 540. Tag signifikant höhere Körpergewichte $(\mathrm{P}<0,05$ bzw. $\mathrm{P}<0,01)$. Das galt auch für die täglichen Zunahmen von der Geburt bis zum 21. Monat $(\mathrm{P}<0,001)$ und vom 6. bis zum 21. Monat $(\mathrm{P}<0,01)$. Keine Unterschiede ergaben sich zwischen den drei Gruppen im OpenField Test oder im Labyrinth. An diesem Tiermaterial konnte festgestellt werden, dass das Wachstum bei diesen Tieren durch die Stellung des Haarwirbels beeinflusst wurde.

Schlüsselwörter: Färsen, Haarwirbel, Wachstum, Verhalten, Holstein Friesian

\section{Introduction}

Handling problems are encountered with dairy cattle to a lesser degree than with beef cattle. However, dairy animals kept in East Central Europe in large herds, and especially heifers calving for the first time, are more prone to exhibiting behaviour that can compromise both stock person's safety and animal welfare (PUPPE, 1996; SAMBRAUS, 1998). It is not easy to anticipate an animal's reaction. That is why we look for visual symptoms that would facilitate this. One of the signs that are very easy to see upon approaching the animal is a facial whorl. If a relationship between hair whorl location and behaviour in exact novel environment or maze could be shown, that may help in identifying potential behaviour problems. It is a possibility that whorl position would be its relation to growth. 
Hair whorls are defined as the spiral of hair with a round epicenter that occurs on the bovine forehead. Hair whorls form from the same layer of cells in the embryo as the nervous system. In humans abnormal hair whorl patterns occur in children with Down's syndrome and Prader-Willi syndrome (GRANDIN, 2002). Hair growth is evident from 18 weeks gestation. Hair whorls may mean more than just a part in the hair pattern. Therefore, absence of a hair whorl or several hair whorls may indicate a primary defect in brain development (CLARK, 2002). Whorl and hair pattern manifestations have been linked to early foetal brain development in humans and further study of facial hair whorl rotation and position may provide useful insight into both behavioural and neurobiological development. This relationships between handedness and hair whorls may be similar in many mammals. The cause of handedness and its relation to the biologically specified scalp hair-whorl rotation has been determined by KLAR (2003). These findings in right-handers and in non-righthanders establish that these traits might develop from a common genetic mechanism. Results suggest that a single gene controls whorl orientation and handedness, and that neuronal and visceral forms of bilateral asymmetry are coded by separate sets of genetic pathways. The direction of the facial hair whorl rotation has been assessed as either radial, clockwise or counter clockwise (MURPHY and ARKINS, 2004). A pattern which is clockwise is dominant, counterclockwise pattern is recessive (BUNNEY, 1994).

The authors have only found two sources concerned evaluation of relationship between whorl position and behaviour in cattle. RANDLE (1998) found in cattle that response to a novel object, cognitive problem solving ability and response to a familiar human were not associated with whorl position. According to results of ABE et al. (2004), cattle with a high whorl position had higher self-grooming behaviour $(\mathrm{p}<0.05)$, resting behaviour $(\mathrm{p}=0.09)$, serum dopamine, and lower serum cortisol $(\mathrm{p}<0.01)$ compared to cattle with a middle position. All other citations were directed exclusively on temperament.

Facial hair whorl position has been shown to be an indicator of individual cattle temperament measured in natural conditions during restraint in a squeeze chute (GRANDIN et al., 1995) or in an auction ring (LANIER et al., 2001). According to them, beef cattle with a hair whorl located above the eyes were nervous and fearful (poor temperament) compared to cattle with a hair whorl located either between the eyes or below the eyes. However, there have been a number of studies that have demonstrated that the behavior of an animal is determined by several factors including the contact with the dam, peers and humans during early development and also genetic influence (SAMBRAUS, 1997; PUPPE, 1996; WEBER and VALLE ZARATE, 2005). The objective of this study was to investigate hypotheses that the growth during rearing (1), number of crossed squares in the arena of open-field test (2) and time traversing the maze (3) in dairy heifers kept in experimental conditions are affected by the height position of facial whorl.

\section{Materials and methods}

Fifty-eight Holstein heifers were used. The heifers originated from 2 sires (BS-19, $\mathrm{n}=27$ and BS-22, $\mathrm{n}=31$ ). Differences between sire lineage's were not significant in any growth or behaviour variables. The experiment and all tests were conducted on the experimental condition on the same farm. 
Heifers were separated from their mothers at 1 or 2 days of age, kept in individual hutches and fed artificial milk until 8 weeks of age. After weaning all heifers were kept together in loose housing bedded pens (in the same barn) according to age and size until the $21^{\text {st }}$ month. The group compositions were the same throughout the study and heifers were housed in pens regardless the distribution of whorl positions.

Calves received $6 \mathrm{~kg}$ of milk replacer per day and could eat starter mixture and alfalfa hay ad libitum until weaning. They received $1.5 \mathrm{~kg}$ of concentrate mixture for heifers per day and alfalfa hay offered ad libitum from weaning to $180 \mathrm{~d}$. From the age of $90 \mathrm{~d}$ they also received corn silage. From the 181st d, all heifers were fed the same diet according to attain $0.75 \mathrm{~kg}$ ADG. Comparable planes of nutrition were ensured in all groups.

Whorl position was recorded by one observer as each heifer entered the weigh-scale. This person was standing in the front of scale, facing the heifer. The epicenter of the hair whorl was used for assignment of position. The hair whorl position was categorised as: „high“ if the whorl was above the top of eyes; „middle“ if the whorl centre was located between the top of the eyes and the bottom of the eyes; and „low“ if the centre was located below the bottom of the eyes (GRANDIN et al., 1995). The heifers were individually weighed at birth and then every month.

An open-field test was conducted in a enclosed building of ethological laboratory (apart of the heifers barn) at two ages: 16 weeks (A1) and 18 months (A2) in an inside arena marked off into 9 squares. Both, Arena A1 (4.5 x 4.5 m) and Arena A2 (10 x 10 $\mathrm{m}$ ) had concrete floors and were visually and acoustically isolated from other animals. The open-field test was carried out between 09.00 and $10.30 \mathrm{~h}$ and lasted for $5 \mathrm{~min}$. The animals were tested individually and always in the same order regardless of hair whorl position. After testing of each heifer, the arena was carefully cleaning by flushing of water. The numbers of crossed squares (NCS) (whenever the animal crossed the square with front feet over a line) were recorded.

The maze learning ability tests were performed in the indoor space with heifers at the age of 15 weeks.

The 6-unit maze was constructed in a 16.4 x $4.5 \mathrm{~m}$ pen. Five barriers were installed inside which marked the beginning and the end of the route and also particular parts of the maze. A bucket with $1 \mathrm{~kg}$ of concentrate mixture was placed at the exit. The heifers had to solve two tasks on two consecutive days. On the first observation day (task A), the passage was open on the left side, and on the right side on the second day (task B). Each day (task), the heifers were tested four times, two runs in the morning and two runs in the afternoon, but before the first test on the first day (task A) was one run for training.

The heifer was allowed to eat for only a ten seconds on successful completion of the maze task. The time taken to traverse the maze (TTM) in the individual runs of both tasks was measured from video tape afterwards, using a stop watch. The animals were tested individually and always in the same order regardless of hair whorl position.

The data were analysed with a statistical package STATISTIX 8 (2003). Among-group comparisons of the BW, ADG, and NCS were analysed using using a General Linear Model ANOVA (General AOV/AOCV). Significant differences between means were tested by Bonferroni's test. Between group comparisons of TTM were tested by Kruskal-Wallis ANOVA comparing mean ranks. Results are expressed as mean \pm s.d. 


\section{Results}

It was found 7 heifers with a high hair whorl, 36 heifers with a middle hair whorl and 15 heifers with a low hair whorl. All whorls were of single round type with a round epicenter.

\section{Growth}

There was no difference between whorl position groups in BW at birth and 180 days, but at $360(\mathrm{P}<0.05)$ and $540(\mathrm{P}<0.01)$ days the high whorl group was heavier than the low whorl group. Further at 540 days the high whorl group was heavier $(\mathrm{P}<0.01)$ than the middle whorl group (Table 1).

Table 1

Live body weights in groups of heifers during rearing (kg) (Lebendmassen in den Versuchsgruppen während der Aufzucht (kg))

\begin{tabular}{lrccc}
\hline Position of the whorl & N & Birth & 360 days & 540 days \\
\hline High & 7 & $39.43 \pm 7.43$ & $328.33 \pm 33.58$ & $455.59 \pm 33.93$ \\
Middle & 36 & $41.67 \pm 3.71$ & $318.84 \pm 28.25$ & $427.47 \pm 30.52$ \\
Low & 15 & $39.87 \pm 7.69$ & $308.77 \pm 32.37$ & $422.85 \pm 42.80$ \\
Significance & & N.S. & H:L ${ }^{*}$ & H:M,L ${ }^{* *}$ \\
${ }^{*} \mathrm{P}<0.05{ }^{* *} \mathrm{P}<0.01$ & N.S. = non significant
\end{tabular}

ADG were highest in heifers with a high hair whorl and lowest in heifers with a low hair whorl position in the period from birth to 21 months of age $(\mathrm{P}<0.001)$ and from the $6^{\text {th }}$ to 21 st month $(\mathrm{P}<0.01)$ (Table 2). Significant differences between groups with a high and a middle hair whorl positions were also found in the same periods $(\mathrm{P}<0.01$; $(\mathrm{P}<0.05)$.

Table 2

Average daily gains in groups of heifers during rearing (kg) (Durchschnittliche Tageszunahmen in den Versuchsgruppen der Färsen während der Aufzucht (kg))

\begin{tabular}{lccc}
\hline Position of the whorl & $\mathrm{N}$ & Birth-21months & 6-21 months \\
\hline High & 7 & $0.75 \pm 0.05$ & $0.74 \pm 0.08$ \\
Middle & 36 & $0.69 \pm 0.05$ & $0.68 \pm 0.09$ \\
Low & 15 & $0.67 \pm 0.09$ & $0.66 \pm 0.11$ \\
Significance & & $\mathrm{H}: \mathrm{L}^{* * *}$ & $\mathrm{H}: \mathrm{L}^{* *}$ \\
& & $\mathrm{H}: \mathrm{M}^{* *}$ & $\mathrm{H}: \mathrm{M}^{*}$ \\
\hline
\end{tabular}

$* \mathrm{P}<0.05 * * \mathrm{P}<0.01 * * * \mathrm{P}<0.001$

\section{Behaviour}

The NCS at the age of 16 weeks was the highest in heifers with a high hair whorl (43.4 \pm 19.8 ), while the lowest number was found in heifers with a low hair whorl (37.8 \pm 19.7$)$.

Heifers with a middle hair whorl displayed for 5 minutes of open-field test at the age of 18 months the highest locomotor behaviour measured by NCS $(37.6 \pm 16.3)$ and heifers with a low hair whorl $(30.8 \pm 11.8)$ were the slowest. However, the differences were not significant.

Differences in the average TTM for all runs were non-significant. Heifers with a high hair whorl were the fastest (77.8 s) and heifers with a middle hair whorl the slowest (87.3 s). The longest TTM were recorded in the first run of the task B, after the change of disposition/configuration of maze and opening the passage to the right side, but differences among groups of animals were not significant. 
Heifers with a high hair whorl adapted the best to the change of the task A on task B, they had the lowest TTM (51.6 s) at the second run and the difference between these animals was significant in comparison with those with a middle hair whorl (125.2 s) $(\mathrm{P}<0.05)$.

\section{Discussion}

According to results of GRANDIN et al. (1995) and LANIER et al. (2001) obtained in feedlot conditions, it is possibility that facial hair whorls may be a useful management tool also in cattle in assessing which animals may become fearful or disturbed in novel environments.

These results indicate that dairy heifers, with a high hair whorl in experimental conditions had significantly higher BW and ADG. It would be important message for husbandry. However, these results can not compare with other authors, because there is lack of similar experiments. Other studies on cattle which we would use for hypothetical explaining indicate that lower growth rate is associated with greater reactivity of animals during handling as indicated by faster flight (BURROW and CORBET, 2002). However, if we could consider behaviour in feedlot conditions observed on the chute and the flight speed as equivalent to our NCS parameter, it would not support our findings about movable animals with higher growth.

The present evaluation could not statistically confirm the second hypothesis that the number of crossed squares in the arena of open-field test is affected by the height position of facial whorl. It could be found that animals with the whorl above the eye level manifested a more intensive locomotor behaviour measured by NCS in openfield tests, but differences among groups with a high, middle and low hair whorl were not significant.

How can explain this? In this investigation were used intensively fed Holstein heifers which were accustomed to regular human contact. The cattle observed in the study of GRANDIN et al. (1995) were extensively raised and had a large flight zone when approached by people because these animals do not have daily close contact with people. According to FRANZ (1999), social conditions can change orienting and exploration in open-field tests and BÜNGER and KAPHENGST (1987) found also that locomotor behaviour of calves in open-field arena was significant affected by housing. On the contrary, heifers used to regular treatment, manipulation and frequent displacements are temperate and cannot express their nature. In the present study the animals came from the same housing and were fed by the same stockperson. May be it was reason why their behavior in open-field test could not so distincly differed. It was used only one open-field test in each age (16 weeks and 18 months), because the repetitions of tests in quick succession cause a habituation (animals learn not to respond to a particular stimulus).

The other ethological test which we applied is generally used in the evaluation of the learning ability and memory of animals (KILGOUR, 1981; ARAVE et al., 1992). But similarly, under the conditions of this experiment, the third hypothesis of an influence of height a whorl above the eye level on the TTM was not confirmed. Heifers with the whorl above the eye level were the fastest in the maze and showed a more intensive and rapid learning behavior, but differences among groups were again non significant. It is very difficult to explain this phenomenon. It was not find it in an attainable scientific literature. There is a lack of sources, nobody has probably dealt with this 
problem except for us. All literature sources about maze behavior were focused on different problems. Design of the maze arena had two alternatives, passage was open to the left side (task A) in the first day or to the right side (task B) in the second day. However, it is difficult and questionable to evaluate side preference and compare it with literature sources on the preference tests, for instance in the milking parlour, because the first task was problem of the left direction. Animals had no possibility to choose. In the present opinion, further study is needed to access the role of position of the whorl to side preference in the maze.

There is problem to explain the mechanism for the relationship between behaviour and production. Individual differences in behaviour are brought about by a multitude of factors. The phenotypic variability of behaviour in animals is influenced not only by genetic causes but also by the interaction between genotype and environment (SAMBRAUS, 1998). Situations of uncertainty, social pressure and fear are potent stressors with relevance for the well-being of animals (BORELL, 2000a; TUCHSCHERER and MANTEUFFEL, 2000). Stress during management procedures with direct human interference might directly alter the stress response (BORELL, 2000b). According to a number of authors the necessity to breed the animals on parameters of behaviour should be taken into consideration also.

In conclusion, the present study found that the growth of live body weight in the investigated population is influenced by their facial whorl position. Results suggest that animals with a high hair whorl may grow faster than animals with a middle or low hair whorl. However, the hair whorl position can be linked to neither locomotor behavior in the open-field test nor the time of solving maze tests. These measures of behavior were not associated with hair whorl position.

\section{References}

ABE, N.; UETAKE, K.; ISHIWATA, T.; EGUCHI, Y.; TANAKA, T.:

The relationship between hair whorl position and behavioural and physiological characteristics in beef cattle. In: Hänninen L and Valros A (eds) Proceedings of the 38th International Congress of the ISAE, (2004), Helsinky, Finland, p. 233

ARAVE, C.W.; LAMB, R.C.; ARAMBEL, M.J.; PURCELL, D.; WALTERS, J.L.:

Behavior and maze learning ability of dairy calves as influenced by housing, sex and sire. Appl. Anim. Behav. Sci., 33 (1992), 149-163

BORELL, E. v.:

Mechanismem der Bewältigung von Stress. Arch. Tierz., Dummerstorf 43 (2000 a), 441-450

BORELL, E. v.:

Stress and coping in farm animals. Arch. Tierz., Dummerstorf 43 (2000 b), Special Issue, 144-152

BUNNEY, S.:

The Cambridge Encyclopedia of Human Evolution. New York: Cambridge University Press, (1994), USA

BÜNGER, U.; KAPHENGST, P.:

Zum Verhalten von Tränkkälbern in einer fremdartigen Umwelt. Mh. Vet. Med., 42 (1987), 378-383

BURROW, H.M.; CORBET, N.J.:

Genetic and environmental factors affecting temperament of zebu and zebu-derived beef cattle grazed at pasture in the tropics. Austr. J. Agric. Res., 51 (2000), 155-162

CLARK, D.P.:

Dermatology for PBL-2. University of Missouri - Coffeepot (2004), 8-14-00

FRANZ, H.:

Methode zur Untersuchung der Lernfähigkeit von Kälbern in Gruppenhaltung und Ergebnisse bei visuellen Differenzierungsaufgaben. Arch. Tierz., Dummerstorf 42 (1999), 241-254

GRANDIN, T.M.; DEESING, J.J.; STRUTHERS, J.; SWINKER, A.M.: 
Cattle with hair whorl paradigms above the eyes are more behaviorally agitated during restraint. Appl. Anim. Behav. Sci., 46 (1995), 117-123

GRANDIN, T.M.:

A new spin on fertility. Beef, (2002) July, p. 16.

KAPHENGST, P.; BÜNGER, U.:

KILGOUR, R.:

Haltung von Tränkkälbern und Open-field-Reaktivität. Arch. Tierz., Berlin 31 (1988), 35-42

Use of the Hebb-Williams closed-field test to study the learning ability of jersey cows. Animal Behav., 29

KLAR, A.J.: (1981), 850-860

Human handedness and scalp hair-whorl direction develop from a common genetic mechanism. Genetics, 165 (2003), 269-276

LANIER, J.L.; GRANDIN, T.; GREEN, R.D.; AVERY, D.; McGEE, K.:

A note on hair whorl position and cattle temperament in the auction ring. Appl. Anim. Behav. Sci., 73 (2001), 93-101

MURPHY, J.; ARKINS, S.:

The orientation of facial hair whorls may be linked to the direction of idiosyncratic motor behaviour in the horse. Proc. Agric. Res. Forum, 1-2 March, Tullamore Court Hotel, Tullamore, Co Offaly, Ireland, (2004), 38-39

PUPPE, B.:

Wohlbefinden bei Nutztieren: eine verhaltensbiologische Übersicht. Biol. Zent.bl., 115 (1996), 3-15

RANDLE, H.D.:

Facial hair whorl position and temperament in cattle. Appl. Anim. Behav. Sci., 56 (1998), 139-147

SAMBRAUS, H.H.:

Tierverhalten - Anzeiger für artgerechte Tierhaltung. Arch. Tierz., Dummerstorf, 40 (1997), Sonderheft, 26-34

SAMBRAUS, H.H.:

Applied ethology - it`s task and limits in veterinary practice. Appl. Anim. Behav. Sci., 59 (1998), 39-48

STATISTIX FOR WINDOWS:

User`s Manual. Analytical Software Statistix 8, P.O.Box 12185, Tallahassee, FL 32317-2185, USA, ISBN 1-881789-06-3, (2003), 396 p.

TUCHSCHERER, M.; MANTEUFFEL, G.:

Die Wirkung von psychischem Stress auf das Immunsystem. Ein weiterer Grund für tiergerechte Haltung (Übersichtsreferat). Arch. Tierz., Dummerstorf, 43 (2000) 6, 547-560

WEBER, R.E.F.; VALLE ZARATE, A.:

Der Begriff Wohlbefinden in der Nutztierhaltung - Diskussion aktueller Definitionsansätze als Grundlage für praxisorientierte Forschung am Beispiel Mastschweinehaltung. Arch. Tierz., Dummerstorf, 43 (2005), 475-489

Received: 2005-11-28

Accepted: 2006-09-19

Corresponding Author

Dipl. Ing. JAN BROUCEK, DrSc.

Forschunginstitut für Tierzucht

SCPV, VUZV, Hlohovska 2, PP 30 C, 94992 NITRA, SLOVAKIA

E-Mail: broucek@scpv.sk 